\title{
ARTIKELEN
}

\section{Wat wordt er nu eigenlijk gezegd? Een verkennend onderzoek naar communicatiepatronen op het Darkweb ${ }^{*}$}

\author{
Tommy van Remunt \& Johan van Wilsem
}

\section{Inleiding}

Cybercriminaliteit is een veelbesproken onderwerp in de samenleving. Criminaliteit gepleegd via het internet - cybercrime - vormt op dit moment een steeds grotere dreiging voor landen, ondernemingen en personen. ${ }^{1}$ Waar cybercriminaliteit in het recente verleden vooral draaide om het hacken van computers, ${ }^{2}$ zijn criminelen zich gaan beseffen dat de toenemende integratie van het internet binnen de huidige samenleving tal van nieuwe mogelijkheden biedt, ${ }^{3}$ met als gevolg dat de dreiging van cybercriminaliteit nu meer dan ooit aan de orde van de dag is. ${ }^{4} \mathrm{Het}$ gaat hierbij niet alleen om de zogenoemde cyber-dependent crimes, vormen van criminaliteit die alleen mogelijk zijn door de aanwezigheid van ICT, zoals hacking, DDoS-aanvallen of malwareverspreiding. Het internet blijkt ook een uitkomst voor de meer klassieke vormen van criminaliteit zoals fraude, diefstal en de drugshandel. Deze vormen van cybercriminaliteit worden ook wel cyber-enabled crimes genoemd. ${ }^{5}$

Waar de beginnende cybercrimineel zich normaliter veelal begeeft op het Clearnet (het reguliere internet), begeeft de gevorderde cybercrimineel zich op het Dark-

* Tommy van Remunt MSc is werkzaam als onderzoeker aan het Instituut voor Strafrecht \& Criminologie van de Universiteit Leiden. Dr. Johan van Wilsem is universitair hoofddocent Criminologie aan het Instituut voor Strafrecht \& Criminologie van de Universiteit Leiden. Gegevens voor dit onderzoek zijn verzameld in het voorjaar van 2015, toen eerstgenoemde auteur als stagiair verbonden was aan Fox-IT. De auteurs zijn Fox-IT en TNO erkentelijk voor het beschikbaar stellen van de data waarmee het in dit artikel besproken onderzoek kon worden uitgevoerd.

1 M.M.L. Domenie e.a., Slachtofferschap in een gedigitaliseerde samenleving. Een onderzoek onder burgers naar e-fraude, hacken en andere veelvoorkomende criminaliteit, Den Haag: Boom Lemma uitgevers 2013; M. Chertoff \& T. Simon, The impact of the dark web on Internet governance and cyber security, Waterloo (Canada): Centre for International Governance Innovation 2015.

2 D. Décary-Hétu \& B. Dupont, 'Reputation in a dark network of online criminals', Global Crime 2013, 14, p. 175-196.

3 R.R. Broadhurst e.a., 'Organizations and cybercrime: An analysis of the nature of groups engaged in cyber crime', International Journal of Cyber Criminology 2014, 8, p. 400-420; T.J. Holt \& A.M. Bossler, 'An assessment of the current state of cybercrime scholarship', Deviant 2014, 35, p. 20-40.

4 E.J. Hilbert, 'Living with cybercrime', Network Security 2013, 11, p. 15-17.

5 M. McGuire \& S. Dowling, Cyber crime: A review of the evidence, Research Report 75, Home Office 2013. 
web, ook wel bekend als het Deep Web of Hidden Web. Het gaat hierbij om een verborgen gedeelte op het internet dat niet via de standaard internetbrowsers toegankelijk is. ${ }^{6}$ Een veelgebruikte manier om het Darkweb te betreden is door gebruik te maken van het Tor-netwerk. ${ }^{7}$ Tor, wat staat voor The Onion Router, ${ }^{8}$ is voor iedereen toegankelijk. Het enige wat men daarvoor hoeft te doen is het downloaden van een speciale Tor-browser, wat kan worden gedaan via een internetbrowser als Internet Explorer of Google Chrome. Middels deze Tor-browser kunnen websites worden bezocht die op het reguliere Clearnet niet zijn te vinden. Deze websites kenmerken zich ten opzichte van andere websites doordat ze de domeinnaam '.onion' hebben. Door gebruik te maken van het Tor-netwerk wordt het IP-adres van de gebruiker geanonimiseerd, waardoor de identiteit en de locatie van de persoon in kwestie niet te identificeren en traceren zijn. Gebruikers van het Tor-netwerk kunnen zich dus anoniem op het internet bewegen. ${ }^{9}$

Uit onderzoek blijkt dat de populariteit van het Tor-netwerk onder cybercriminelen nog steeds rijzende is, evenals de omvang van de geldtransacties die erin omgaan. ${ }^{10}$ De anonimiteit die door het Tor-netwerk wordt verschaft en gewaarborgd, is een van de belangrijkste motivaties voor criminelen om gebruik te maken van het Darkweb. ${ }^{11}$ Daarnaast biedt het netwerk de mogelijkheid voor bepaalde reguliere beroepsgroepen, zoals journalisten en rechercheurs, voor wie het beter en veiliger is dat hun identiteit anoniem blijft, om in contact te komen met bijvoorbeeld infiltranten, criminelen en klokkenluiders. Daarnaast biedt het Tor-netwerk kansen aan mensen in landen als China, Noord-Korea en Syrië, waar het internet onder strenge censuur staat of klokkenluiders vervolgd kunnen worden, om op een veilige en anonieme manier met elkaar en de buitenwereld te kunnen communiceren. ${ }^{12}$

Buiten dat het internet een steeds centralere rol krijgt binnen het daadwerkelijk plegen van criminaliteit, wordt het internet ook steeds vaker als belangrijk communicatiemedium gezien in de voorbereidingsfase van een crimineel delict. Hiervoor verplaatsen cybercriminelen zich naar online platforms (internetfora) op het Darkweb. Het gaat hierbij om virtuele ontmoetingsruimten die voor iedereen toe-

6 Zie bijv. A. Yadav, 'Insights of Deep Web: What Google can't search', International Journal of Engineering Sciences \& Research Technology 2014, p. 796-799.

7 Chertoff \& Simon 2015.

8 J. Martin, 'Lost on the Silk Road: Online drug distribution and the "cryptomarket"', Criminology \& Criminal Justice 2013, 14, p. 351-367.

9 N. Christin, 'Traveling the Silk Road: A measurement analysis of a large anonymous online marketplace. In Proceedings of the 22nd international conference on World Wide Web', International World Wide Web Conferences steering Committee 2012, p. 213-224.

10 Zie bijv. M.J. Barrat, J.A. Ferris \& A.R. Winstock, 'Use of Silk Road, the online drugs marketplace, in the United Kingdom, Australia and the United States', Addiction 2014, 109, p. 774-783; D.S. Dolliver, 'Evaluating drug trafficking on the Tor Network: Silk Road 2, the sequel', International Journal of Drug Policy 2015, DOI: 10.1016/j.drugpo.2015.01.008.

11 M.C. van Hout \& T. Bingham, 'Responsible vendors, intelligent consumers: Silk Road, the online revolution in drug trading', International Journal of Drug Policy 2014, 25, p. 183-189.

12 R. Khanna, V. Dhingra \& K. Choudhary, 'Internet censorship: Freedom vs security', International Journal of Computer Trends and Technology 2013, 4, p. 2698-2700; B. Warf, 'Geographies of global Internet censorship', GeoJournal 2013, 76, p. 1-23. 
gankelijk zijn en waar op anonieme wijze contact met elkaar kan worden gezocht. ${ }^{13}$ Deze online platforms worden niet alleen gebruikt voor het uitwisselen van informatie, maar staan ook bekend als online markten waar wordt gehandeld in (illegale) goederen en services als drugs, wapens, identiteitspapieren en malware. Het aantal deelnemers binnen deze fora groeit al jaren en zal naar verwachting, mede gezien het toenemende gebruiksgemak, ook de komende jaren blijven groeien. ${ }^{14}$ De aanwezigheid van websites als Google en YouTube, waar online handleidingen beschikbaar zijn over hoe met het internet omgegaan kan worden of waar criminele goederen als drugs, wapens of malware te koop zijn, maakt het tenslotte gemakkelijker voor mensen om de toegang te vinden tot het Darkweb en deel te nemen aan de online zwarte markten. ${ }^{15}$

Het is opvallend dat ondanks de toename van het gebruik van het Darkweb en zijn online zwarte markten de kennis over hoe men zich binnen deze omgeving gedraagt gering is, enkele uitzonderingen daargelaten.

\section{Online zwarte markten in eerder onderzoek}

Hutchings en Holt hebben aan de hand van tekstanalyse van berichten op het Darkweb geprobeerd om een zogenoemd crime script vast te stellen voor de activiteiten op online zwarte markten waarbij gestolen goederen worden verhandeld. ${ }^{16}$ Crime scripts laten acties en besluiten van criminelen van voor, tijdens en na het delict zien, waardoor een gedetailleerd beeld ontstaat van de totale criminele handeling en wat daarbij de rol is van het online forum. ${ }^{17}$ De focus ligt daarbij op standaardhandelingen in uiteenlopende fases; die geven in die zin ook richting aan de manier waarop het proces van criminaliteit in die fases gefrustreerd kan worden. ${ }^{18}$ Crime scripts leggen daarmee de 'zwakke plekken' binnen de uitvoering van een crimineel delict bloot, wat de mogelijkheid biedt voor opsporingsinstanties om op die situaties strategische preventiemaatregelen aan te passen. De studie van Chiu, Leclerc en Townsley is een goed voorbeeld waarbij een crime script is opgesteld met betrekking tot illegale drugslaboratoria, waar vervolgens proactieve preventiestrategieën uit voortvloeien. ${ }^{19}$ De onderzoekers hebben in dit onderzoek het proces blootgelegd van de handel in 'illegale' drugs, waarbij zij per fase in het proces hebben vastgesteld wat er door de criminelen wordt gedaan om de criminele activiteiten af te schermen voor de buitenwereld. Op basis van deze

13 L. Ablon, M.C. Libicki \& A.A. Golay, Markets for cybercrime tools and stolen data, Rand Corporation: National Research Devision 2014.

14 Idem.

15 Idem.

16 A. Hutchings \& T.J. Holt, 'A crime script analysis of the online stolen data market', The British Journal of Criminology 2014, DOI: 10.1093.

17 D.B. Cornish, The procedural analysis of offending and its relevance for situational prevention, geraadpleegd op 4 maart 2015, via http://citeseerx.ist.psu.edu/viewdoc/download?doi=10.1.1.375. 8084\&rep=rep1\&type=pdf; D.B. Cornish \& R.V. Clarke, 'Analyzed organized crimes', in: A. Piquero \& S. Tibbetts (red.), Rational choice and criminal behaviour, Londen: Routledge 2002.

18 R.V. Clarke \& D.B. Cornish, 'Modeling offenders' decisions: A framework for research and policy', Crime and Justice 1985, 6, p. 147-185.

19 Y. Chiu, B. Leclerc \& M. Townsley, 'Crime script analysis of drug manufacturing in clandestine laboratories', British Journal of Criminology 2011, 51, p. 355-374. 
bevindingen worden er voorstellen geopperd op welk moment in het proces en op welke manier opsporingsinstanties kunnen ingrijpen om verdere illegaliteit te voorkomen.

Hutchings en Holt hebben voor het onderzoek 1889 berichten tussen kopers en verkopers van 13 verschillende Engels- en Russischtalige fora middels een contentanalyse geanalyseerd $(N=1889)$. Hier is een crime script uit voortgekomen waarbij negen verschillende fases zijn te onderscheiden omtrent de handel in goederen en diensten op het Darkweb. Het gaat hierbij om de voorbereidingsfase, de fase van toetreding tot het forum, het verkrijgen of vervaardigen van (criminele) producten en diensten, de verificatiefase, het daadwerkelijk gebruikmaken van het forum, het maken van afspraken met afnemers, de fase van het transporteren van de verhandelde goederen, het afhandelen van de transactie en de fase van het reputatiemanagement. De rol van het forum hierin is het bieden van een virtuele ruimte aan personen om met elkaar te communiceren en om aan andere forumgebruikers zichtbaar te maken of een transactie tussen twee partijen goed verloopt of niet.

Een ander voorbeeld waarbij een crime script is opgesteld van handelingen op Darkweb-fora is de studie van Soudijn en Monsma, waarbij 1700 forumberichten zijn onderworpen aan een kwantitatieve analyse. Verder zijn er steekproefsgewijs langere threads op kwalitatieve wijze geanalyseerd. ${ }^{20}$ Het forum dat binnen dit onderzoek centraal stond, hanteerde de regel dat het daadwerkelijk doen van (criminele) zaken op het forum niet was toegestaan. Als gevolg van deze regels weken forumgebruikers uit naar andere communicatiemiddelen om zaken te kunnen doen, zoals chatrooms of versleutelde mailberichten. Het forum verschaft daarmee dus wel inzicht in het soort goederen of diensten dat wordt aangeboden, evenals de richting van de communicatie, maar niet de inhoud van het zakelijk overleg tussen de forumleden en hoe vaak er daadwerkelijk transacties hebben plaatsgevonden. Logischerwijs is het crime script dat hieruit volgt dan ook een stuk korter dan het eerder beschreven crime script van Hutchings en Holt. Dit crime script stopt namelijk op het moment dat de verkoper zijn advertentie heeft geplaatst of de koper zijn wensen heeft gepubliceerd middels het plaatsen van één of meerdere forumberichten. In dit type forumbericht, dat ook als advertentie gezien kan worden, is opgenomen op welke manier verder contact mogelijk is. De onderhandelingen en exacte afspraken worden vervolgens niet op het forum geregeld, maar via andere versleutelde kanalen. Het forum kan in deze situatie dus worden bestempeld als een virtuele ontmoetingsruimte. De verdere samenwerking, afspraken en onderhandelingen vinden buiten het forum plaats. ${ }^{21}$ Daarbij valt het binnen het onderzoek van Soudijn en Monsma op dat het merendeel van het aantal berichten op een forum door slechts een kleine groep forumgebruikers wordt geschreven. Ten slotte is er geconstateerd dat forumleden over langere tijdsperiodes meer nieuwe relaties aangaan. Dit kan verklaard worden doordat het netwerk met de tijd groeit, waardoor er ook meer contactmogelijkheden zijn.

20 M. Soudijn \& E. Monsma, 'Virtuele ontmoetingsruimtes voor cybercriminelen', Tijdschrift voor Criminologie 2012, 54, p. 349-360.

21 Holt 2013. 
De studie van Van Hout en Bingham naar Darkweb-fora laat een kwalitatief onderzoek zien naar beweegredenen van forumgebruikers op het Darkweb. ${ }^{22}$ In deze studie hebben de onderzoekers tien forumleden van het Darkweb-forum Silk Road geïnterviewd door middel van de aanwezige chatbox op het forum, waardoor de respondenten volledig anoniem blijven. Ten tijde van de interviews waren vijf respondenten werkloos, hadden vier personen een fulltime baan en volgde er één nog een studie. De respondenten geven allemaal aan dat zij bekend zijn met het Darkweb en het gebruik van het forum Silk Road. De reden die het vaakst wordt gegeven waarom deze personen gebruikmaken van het Darkweb-forum, is de interesse in drugs. De keuze om gebruik te maken van het Silk Road-forum valt hier dan ook volledig aan te wijten. Silk Road stond op het Darkweb hoog aangeschreven wanneer het gaat om de handel in drugs. Er is een ruime keuze aan soorten drugs, waarbij de kwaliteit als hoog wordt bestempeld en de verkopers als betrouwbaar. Alle respondenten geven aan dan ook wel eens drugs gekocht te hebben. Het lijkt er dan ook op dat het toch wel klassieke delict 'drugshandel' zich verplaatst naar de virtuele wereld. Een van de respondenten geeft in het volgende citaat aan waarom er meer vertrouwen is in de digitale markt dan in de straatmarkt: 'The streetmarket is more risky for everyone. It doesn't have feedback or rating available for every buyer to read. You are more likely to be involved with people who might not be concerned in your welfare' (p. 186). De feedback waar in dit citaat over wordt gesproken, komt voort uit de fase van reputatiemanagement die Hutchings en Holt benoemen in hun crimescript. ${ }^{23}$ Hoewel de anonimiteit blijkbaar een belangrijke voorwaarde is om gebruik te maken van het Darkweb, blijkt dus dat forumgebruikers daarentegen wel waarde hechten aan een zichtbaar gegeven van vertrouwen.

\section{Onderzoeksvraag en doelstellingen}

De hiervoor genoemde studies laten zien dat er al wel een aantal onderzoeken is uitgevoerd naar internetfora op het Darkweb, maar tegelijkertijd dat dit type onderzoek nog altijd in de kinderschoenen staat. Zo is het opvallend dat voornoemde studies zich voornamelijk richten op specifieke online gedragingen gerelateerd aan criminele activiteiten, terwijl er nog vrijwel niets bekend is over de werkende mechanismen op een dergelijk forum. Waar bestaat zo'n forum nu eigenlijk uit? Wat voor mensen maken hier gebruik van? En wat wordt er nu eigenlijk gezegd? Het blijkt dan ook dat het in de reeds bekende wetenschappelijke literatuur ontbreekt aan beschrijvende studies naar communicatiepatronen op Darkweb-fora, zoals typerende kenmerken van forumgesprekken, -berichten en -gebruikers; kennis die voor efficiëntie en effectieve bestrijdingsmethoden van criminele gedragingen op het Darkweb toch van essentieel belang kunnen zijn. Immers, hoe meer kennis er is over dit fenomeen, hoe beter en professioneler deze kan worden toegepast door de verschillende opsporingsinstanties. In deze bijdrage staat daarom ook de volgende onderzoeksvraag centraal: In hoeverre is het mogelijk om communicatiepatronen te ontdekken bij verschillende soorten forumgebrui- 
kers binnen een online Darkweb-forum? Met deze onderzoeksvraag wordt geprobeerd een tweeledig doel te bereiken. Op de eerste plaats is dit onderzoek uitgevoerd om een gedeelte van de leemtes in het reeds bekende wetenschappelijk onderzoek naar de digitale onderwereld op te vullen. Op de tweede plaats toont deze studie de waarde van kwantitatief onderzoek naar Darkweb-fora aan, en dient ze daarmee met name als startpunt voor toekomstig Nederlands onderzoek naar online gedragingen van personen op Darkweb-fora.

In de onderzoeksvraag wordt de term 'verschillende soorten forumgebruikers' gebruikt. In het forum dat centraal staat binnen dit onderzoek, het Agora-webforum, wordt deze term ingekleurd aan de hand van user-titles. Deze user-titles geven aan welke positie iemand inneemt binnen de geldende hiërarchie. Wanneer een forumgebruiker nieuw is op het forum, krijgt deze persoon de status van Newbie. Bij het plaatsen van vijf berichten in vijf verschillende threads stijgt iemand in ranking naar de status Junior Member, waarna achtereenvolgens de status van Full Member, Senior Member en Hero Member bereikt kunnen worden. Hoe meer berichten iemand dus plaatst, hoe hoger men stijgt in de geldende ranking op het forum. Zoals eerder vermeld, blijkt uit het onderzoek van Soudijn en Monsma $^{24}$ dat senioriteit op een forum leidt tot verschillen in het aantal online relaties die iemand aangaat. Binnen het huidige onderzoek wordt gekeken of senioriteit ook samenhangt met hoe men zich manifesteert op een forum. Naast de hiërarchische indeling van members worden op het forum nog drie andere rollen onderscheiden. Op de eerste plaats is er de rol van Vendor. Wanneer een forumgebruiker goederen of diensten wil verkopen op het forum, moet deze persoon eerst een speciaal Vendor-account aanvragen. Het gaat hier bijvoorbeeld over de handel in drugs, informatie, identiteit, creditkaarten of malware. ${ }^{25}$ Een forumgebruiker kan een Agora-Vendor worden wanneer er al een Vendor-account is aangemaakt op het forum Silk Road of op het forum Black Market Reloaded. Wanneer men niet over een dergelijk account beschikt, is het mogelijk voor zowel nieuwe als huidige forumleden om een Vendor te worden door middel van het betalen van een borg van 0,6 bitcoins ${ }^{26}$. Deze borg kan men terugvragen wanneer men besluit om het Vendor-account op te heffen. Hiervoor is het wel van belang dat de Vendor in kwestie geen oplichter blijkt te zijn.

Naast de Vendor kent het forum de rol van Administrator. Het gaat hierbij om personen die het forum beheren en in sommige situaties genoodzaakt zijn om mededelingen te doen op het forum of op forumberichten te reageren. Ten slotte kunnen mensen zich als Guest aanmelden op het forum en op deze manier reageren op forumberichten. Deze laatste drie rollen staan los van de hiervoor omschreven hiërarchische verhouding en zijn niet afhankelijk van een aantal geplaatste berichten.

25 L. Paulissen \& J. van Wilsem, Dat heeft iemand anders gedaan!, Amsterdam: Reed Business 2015, hoofdstuk 6; Soudijn \& Monsma 2012; Hutchings \& Holt 2012.

26 De bitcoin is een online betaalmiddel. Net als bij andere valuta is de waarde van bitcoins afhankelijk van de geldende wisselkoers. Op 3 november 2015 stond 1 bitcoin gelijk aan $€ 334,75$. 


\section{Onderzoeksopzet}

\section{Data}

Voordat verder wordt ingegaan op de onderzoeksmethode, is het goed om op voorhand kort stil te staan bij de terminologie waarmee gedurende het onderzoek is gewerkt. Zoals eerder vermeld is een webforum een virtuele ontmoetingsruimte op het internet die de mogelijkheid biedt voor individuen om met elkaar in contact te komen en discussies met elkaar aan te gaan. ${ }^{27}$ Een webforum bestaat uit threads, die worden gestart wanneer een geregistreerde forumgebruiker een vraag stelt of een statement maakt omtrent een bepaald onderwerp. ${ }^{28}$ Het forum staat andere forumgebruikers toe om hier op te reageren, waardoor er een conversatie ontstaat. Threads bestaan dus uit een $\mathrm{x}$-aantal berichten gecentreerd rond een bepaald onderwerp.

Het forum dat centraal staat in dit onderzoek is het Agora-webforum. Agora is gelanceerd in december 2013 en behoort op het moment van schrijven tot een van de grootste online zwarte markten. ${ }^{29}$ Om de veiligheid en anonimiteit van het forum en zijn gebruikers te waarborgen wordt het forum, evenals veel andere online markten, regelmatig voor onbepaalde tijd van het web gehaald. Middels deze weg wordt geprobeerd om onder andere DDoS-aanvallen te voorkomen en zo veel mogelijk onzichtbaar te blijven voor opsporingsinstanties. Mede door deze preventieve acties, strenge reglementen en het open karakter van het forum staat Agora binnen de digitale onderwereld hoog aangeschreven als het gaat om betrouwbaarheid, toegankelijkheid en bruikbaarheid. ${ }^{30}$

\section{Procedure}

Voor dit onderzoek is gebruikgemaakt van gegevens uit de DarkWeb-monitor. ${ }^{31}$ Deze tool verzamelt en monitort op het moment van schrijven gegevens van twaalf verschillende Darkweb-fora, bestaande uit duizenden forumthreads en miljoenen forumberichten. Vanwege de omvangrijke data die de monitor herbergt, is voor het onderzoek gekozen om gebruik te maken van een steekproef. Voor deze steekproeftrekking is binnen de monitor gezocht naar Engelstalige berichten die geschreven zijn in de periode 1 januari 2014 tot en met 31 december 2014 op het Agora-webforum. Gezien de reikwijdte van het Darkweb is ervoor gekozen om een afgebakende steekproef te creëren. Hiervoor zijn in de monitor de zoekfilters met de termen 'Vendor' en 'Malware' zo afgesteld dat verondersteld mocht worden dat er een dataset gecreëerd wordt waarbij handel in malware centraal staat. Malware is bij uitstek een goed dat via het internet verhandeld kan

27 T.J. Holt \& E. Lampke, 'Exploring stolen data markets online: products and market forces', Criminal Justice Studies 2010, 23, p. 33-50.

28 Idem.

29 The uncensored hidden wiki, Agora, geraadpleegd op 2 april 2015, via http://kpvz7kpmcmne52qf. onion.city/wiki/index.php/Agora

30 Idem.

31 Voor dit onderzoek is de DarkWeb-monitor beschikbaar gesteld door Fox-IT en TNO. Het gaat hierbij om een project waarbij verschillende Darkweb-forums worden gemonitord. 
worden. Het is dan ook de verwachting dat we met deze steekproef een specifiek op malwarehandel gerichte dataset hebben samengesteld.

Deze zoekopdracht binnen de monitor levert 198 verschillende threads $(N=198)$ op. Omdat er grote verschillen zitten tussen de omvang van de threads (die variëren van één tot duizenden berichten), is ervoor gekozen om alleen de eerste 15 berichten van een thread mee te nemen in de analyse. Dit heeft ertoe geleid dat 112 threads (56,6\%) volledig zijn meegenomen in de steekproef, terwijl er bij 86 threads $(43,4 \%)$ één of meerdere berichten buiten beschouwing zijn gelaten. Uiteindelijk bestaat de steekproef uit 2182 unieke forumberichten.

\section{Onderzoeksmethode en variabelen}

Voor dit onderzoek is gekozen om net als bij het eerder besproken onderzoek van Hutchings en Holt gebruik te maken van contentanalyse. ${ }^{32}$ Het gaat hierbij om een onderzoeksmethode waarbij tekst op een systematische wijze wordt geanalyseerd, met als doel het verwerven van nieuwe kennis, inzichten en een andere representatie van de feiten. ${ }^{33}$ Het gaat om een interdisciplinaire methode voor het doen van onderzoek naar interacties tussen mensen, waarbij gebruik kan worden gemaakt van zowel een kwantitatieve als een kwalitatieve insteek, en is mede daardoor dus een geschikte methode voor de analyse van internetfora. ${ }^{34}$ Waar het analyseren van internetgegevens regelmatig op een geautomatiseerde wijze via webcrawlers wordt uitgevoerd, zijn in het huidige onderzoek alle threads en berichten handmatig ingezien en beoordeeld.

Bij het opstellen van de coderingslijst is zowel een inductieve als een deductieve aanpak gehanteerd. ${ }^{35}$ De lijst met variabelen is aangevuld naar aanleiding van de bestudeerde onderzoeken met betrekking tot het Darkweb (de deductieve aanpak), terwijl ook gekeken is naar de mogelijkheden die de DarkWeb-monitor biedt zonder daarbij rekening te houden met een theoretische achtergrond (de inductieve aanpak). Voor de threads zijn de volgende variabelen in het databestand opgenomen: titel van de thread, datum van het eerste en laatste bericht, aantal berichten in thread, naam van een berichtgever, intentie van de threadstarter, crimineel delict en threadkenmerken als de humoristische, kleinerende of agressieve ondertoon van de thread (zie tabel 1 voor een overzicht van de verschillende categorieën per variabele).

Ten slotte zijn er nog variabelen aan het databestand toegevoegd die niet specifiek kijken naar de threads, maar naar de forumgebruikers en forumberichten. Het gaat hierbij om de variabelen user-title, taal waarin het bericht is geschreven, type forumgebruiker en type forumbericht (zie tabel 2). Aan de hand van deze code-

32 F. Henri, 'Computer conferencing and content analysis', in: A.R. Kaye (red.), Collaborative learning through computer conferencing: The Najaden Papers, New York: Springer 1992, p. 115-136.

33 S. Elo \& H. Kyngäs, 'The qualitative content analysis process', Journal of Advanced Nursing 2008, 62, p. 107-115.

34 Donneley \& Gardner 2011; B. Jordan \& A. Hederson, 'Interaction analysis: foundations and practice', The Journal of the Learning Sciences 1995, 4, p. 39-103; R. Donneley \& J. Gardner, 'Content analysis of computer conferencing transcripts', Interactive Learning Environments 2011, 19, p. 303-315. 
Tabel 1 Beschrijving threadkenmerken

\begin{tabular}{lll}
\hline & Aantal & Percentage \\
\hline Totaal aantal threads & 198 & 100 \\
Totaal aantal berichten & 25782 & 100 \\
Kortste thread, aantal berichten & 1 & \\
Langste thread, aantal berichten & 8050 & \\
Gemiddeld aantal berichten & 130 & \\
Kortste thread, aantal dagen & 1 & \\
Langste thread, aantal dagen & 765 & \\
Aantal dagen: gemiddelde & 64 & \\
Aantal dagen: mediaan & 6 & \\
Variabelen over threads & & \\
Intentie van de threadstarter & & \\
Crimineel delict & 38 & 19,2 \\
Informatie inwinnen & 76 & 38,4 \\
Discussie starten & 63 & 31,8 \\
Anders & 21 & 10,6 \\
Crimineel delict & & \\
Drugs & 47 & 23,7 \\
Malware & 98,1 \\
Carding & 28 & 17,2 \\
DDoS & 12 & 1,0 \\
Geen & 139 & 0,5 \\
Threadkenmerken & & 70,2 \\
Status & & \\
Agressie & & \\
Humor & & \\
\hline
\end{tabular}

ringslijst zijn alle 198 threads en 2182 berichten uit de steekproef handmatig geanalyseerd en ingevoerd in een SPSS- bestand.

Analyse

Voor het beschrijvende doel van dit onderzoek is ervoor gekozen om een kruistabel op te stellen waarbij forumusers, aan de hand van user-titles, centraal staan en gelinkt worden aan de variabelen type forumgebruiker en het type delict. Daarbij is er gezocht naar significante verbanden tussen de verschillende variabelen aan de hand van de chikwadraattoets. De resultaten van deze analyse zullen daar waar nodig worden ondersteund met citaten afkomstig van de forumberichten. 
Tabel 2 Beschrijving berichtkenmerken

\begin{tabular}{lll}
\hline & Aantal & Percentage \\
\hline Aantal berichten in analyse & 2182 & 100 \\
Aantal unieke forumgebruikers & 789 & 100 \\
Taal van de berichten & & \\
$\quad$ Engels & 1946 & 89,2 \\
Niet geclassificeerd & 234 & 10,7 \\
Anders & 2 & 0,1 \\
User-titles & & \\
Newbie & 212 & 9,7 \\
Jr. Member & 177 & 8,1 \\
Full Member & 610 & 28,0 \\
Sr. Member & 298 & 13,7 \\
Hero Member & 390 & 17,9 \\
Vendors & 465 & 21,3 \\
Administrator & 21 & 1,0 \\
Guest & 9 & 0,4 \\
Type forumgebruiker & & \\
Aanbieder crim. goed & 73 & 3,3 \\
Vrager crim. goed & 10 & 0,5 \\
Reviewer & 143 & 6,6 \\
Vraag m.b.t. forum & 89 & 4,1 \\
Reageerder & 1857 & 85,1 \\
Anders & 10 & 0,5 \\
\hline
\end{tabular}

\section{Resultaten}

In tabel 3 zijn de resultaten opgenomen van de analyse die is uitgevoerd op de 198 verschillende threads, bestaande uit 2182 forumberichten. Wanneer wordt gekeken naar de totalen in deze tabel, valt direct het volume op aan 'reactieberichten': dit is $85 \%$ van alle geanalyseerde berichten. Het gaat hierbij om berichten die een directe reactie vormen op eerder geplaatste berichten, zoals bijvoorbeeld de mening van forumgebruikers, een aanvullend antwoord van een derde persoon of het bedanken of bevestigen van een bepaald bericht. Ruim $6 \%$ van de geanalyseerde berichten bestaat uit reviews over de samenwerkingen die forumgebruikers met elkaar zijn aangegaan, en in circa $4 \%$ van de berichten wordt er concreet over criminele handelingen gesproken in termen van vraag en aanbod. Daarnaast blijkt uit de tabel dat in meer dan de helft van het aantal berichten wordt gesproken over concrete criminele delicten, waarbij de delicten drugs en DDoS met respectievelijk 20,5 en 18,7\% de boventoon voeren binnen alle geanalyseerde berichten. Gezien de keuzes die gemaakt zijn bij de steekproeftrekking, is 
het opvallend dat er in slechts $13,1 \%$ van de berichten wordt gesproken over malware.

Naast deze bevindingen uit de totaalkolom laat tabel 3 een aantal significante verbanden zien tussen de verschillende variabelen. Omdat het op dit moment nog ontbreekt aan vergelijkbaar onderzoek naar forumgebruikers op het Darkweb, is het lastig om de huidige resultaten in het juiste perspectief te plaatsen. Daarom moet er met een oriënterende en verkennende blik naar deze resultaten worden gekeken, waarbij tabel 3 moet worden bekeken met de vraag of de resultaten logisch en verklaarbaar zijn.

Wanneer forumgebruikers nieuw zijn op het forum, krijgen zij het stempel Newbie. Het is opvallend dat deze groep significant vaker start met het schrijven van een thread dan de andere aanwezige groepen. Mogelijke verklaringen hiervoor zijn dat forumgebruikers nieuw zijn en zichzelf willen voorstellen of met vragen zitten over het forumgebruik. Een andere verklaring hiervoor kan worden gevonden in het schrijven van reviews, een activiteit die bij Newbies met ruim $11 \%$ significant vaker voorkomt dan bij andere groepen. Dit kan mogelijk worden verklaard doordat forumgebruikers een tweede forumaccount aanmaken om alleen anoniem positieve reviews over zichzelf te schrijven. Immers, hoe meer positieve reviews iemand ontvangt, hoe hoger deze in aanzien stijgt ten opzichte van andere forumgebruikers. Aan de andere kant, zoals blijkt uit het volgende citaat, is dit een bekende truc op het Darkweb, waardoor het nog maar de vraag is in hoeverre reviews van Newbies dan ook daadwerkelijk van toegevoegde waarde zijn voor forumgebruikers: 'Stop shilling. These are clearly all the same person trying to boost the rep of a unverified vendor'. Omdat dit forumaccount geen verdere geschiedenis heeft op het forum, zal het niet snel worden vertrouwd door de overige forumgebruikers, waardoor er weinig waarde aan dergelijke reviews zal worden gehecht. De laatste opvallende factor binnen deze groep is dat Newbies, in tegenstelling tot bepaalde andere groepen, relatief weinig berichten plaatsen over criminele delicten.

De volgende groep user-titles in de hiërarchie bestaat uit Jr. Members, van wie gezien de hogere ranking verwacht mag worden dat zij met serieuzere bedoelingen op het forum actief zijn. Het is daarom wellicht ook dat Jr. Members significant vaker vragen stellen met betrekking tot het forum ten opzichte van andere groepen. Verder lijken Jr. Members in meerdere facetten op Newbies. Zo worden er veel reviews geschreven en wordt er relatief weinig over malware gesproken. Naast de vergelijking met Newbies vertoont deze groep ook overeenkomsten met de groep Full Members (die dan wel weer meer forumberichten hebben geplaatst). Het verschil tussen beide groepen lijkt te zijn dat Full Members minder vaak vragen stellen over het forumgebruik, waarschijnlijk omdat zij al langduriger actief zijn op het forum dan de twee voorgaande groepen. Verder valt het op dat Full Members bovengemiddeld veel communiceren over wapens, terwijl zij bij berichten omtrent malware en drugs significant minder betrokken zijn. De volgende groep in de hiërarchie, de Sr. Members, scoort op vrijwel alle variabelen een gemiddelde score. Binnen deze groep valt vooral het relatief lage aantal berichten op omtrent malware, een delictsvorm waar zij dus weinig bij betrokken zijn. Dat 
geldt niet voor de laatste groep in de hiërarchie, de Hero Members. Dit is de groep die verreweg het meest actief is in berichten over malware, bijna drie keer vaker dan gemiddeld. Deze groep is daarentegen minder betrokken bij berichten over drugs, initieert relatief weinig aanbod van criminaliteit, maar reageert juist relatief veel op andermans berichten.

De eerste groep buiten de hiërarchische indeling in de tabel is de groep Vendors. Het gaat hierbij om de groep forumgebruikers die het voorrecht hebben om te mogen handelen in goederen en diensten op het forum. Het is dan ook niet verwonderlijk dat Vendors significant vaker producten of diensten aanbieden op het forum ten opzichte van de andere groepen. Daarentegen is het wel opvallend dat het soms voorkomt dat andere groepen user-titles ook criminele goederen aanbieden, terwijl dat officieel volgens de forumregels niet mag. Verder blijkt uit deze tabel dat Vendors het vaakst te maken hebben met drugsdelicten $(35,3 \%)$. Ook wordt er significant gescoord op de delicten DDoS en malware, maar deze percentages blijven met 12,5 en $8,8 \%$ toch lager dan het steekproefgemiddelde van respectievelijk 18,7 en $13,1 \%$. De laatste opvallende bevinding binnen deze groep heeft te maken met de reviews. Deze worden door Vendors ten opzichte van de andere groepen verreweg het minste geplaatst. Deze bevinding is echter ook naar verwachting, gezien het gebruikelijk is dat de consument de transactie met de verkopers beoordeelt.

De invloed van de laatste twee groepen op het forum, de Administrators en de Guests, is zoals verwacht beperkt. Dit kan worden verklaard door de invulling van de rol die beide user-titles vervullen op het forum. De Administrator behoudt het overzicht op het forum en laat alleen van zich horen wanneer dit nodig wordt geacht. De Guest daarentegen is slechts eenmalig actief op het forum. Wanneer iemand immers van plan is om zich actiever op het forum te manifesteren, mag worden verwacht dat er een echt forumaccount wordt aangemaakt, zodat zijn activiteiten zichtbaar worden voor andere forumgebruikers, waardoor hij geloofwaardig kan acteren op het forum.

Ten slotte blijkt uit tabel 3 dat de veronderstelling die gemaakt is bij het instellen van de zoekfilters binnen de DarkWeb-monitor onjuist blijkt. Waar de zoekfilters zo zijn ingesteld met de veronderstelling dat de dataset vooral zou bestaan uit berichten omtrent malwarehandel, blijkt dit in werkelijkheid een misvatting. In $3,3 \%$ van de berichten wordt er slechts gesproken over het aanbieden van criminele goederen, en in 13,1\% wordt er gesproken over malware. Gezien de aard van het onderzoek, het beter leren begrijpen van Darkweb-fora door middel van een beschrijvende analyse, kent deze misvatting overigens geen consequenties voor het onderzoek. Wel betekent het dat de steekproeftrekkingsmethoden weloverwegen plaats moeten vinden - we komen daar in de discussie van dit artikel nog kort op terug. 


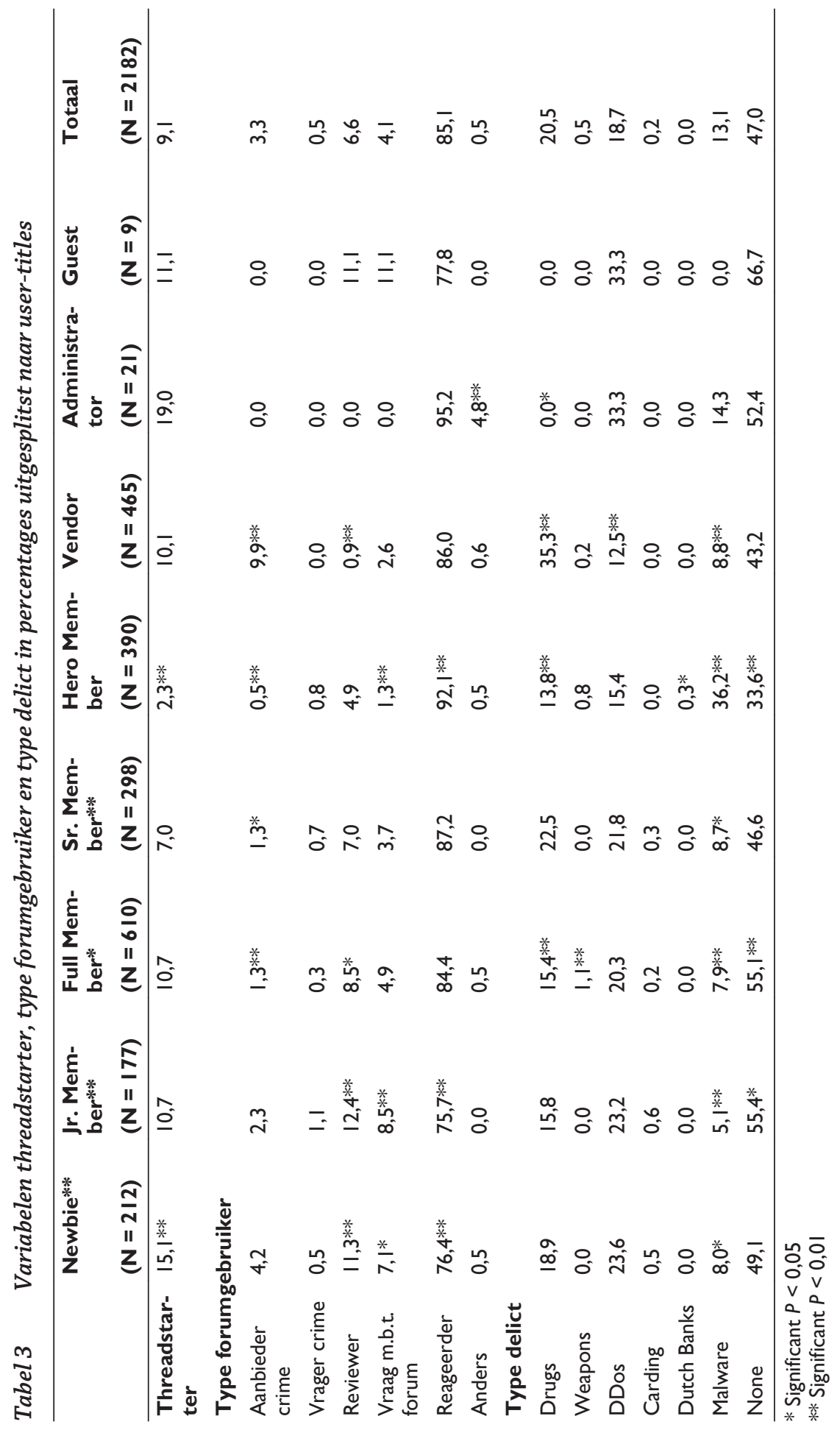




\section{Conclusie}

In dit onderzoek staat de vraag centraal 'In hoeverre zijn er communicatiepatronen te ontdekken binnen een online Darkweb-forum', waarbij de rol van forumgebruikers, uitgedrukt in user-titles, als uitgangspunt is genomen. Dat de alsmaar toenemende integratie van het internet in de maatschappij legio kansen biedt aan diezelfde maatschappij, staat buiten kijf. Deze ontwikkeling kent echter ook een keerzijde, mede door de kansen die het internet biedt aan criminelen. ${ }^{36}$ Middels het zogenoemde Tor-netwerk, een zijweg die het internet biedt, is het mogelijk om het zogeheten Darkweb te betreden, waardoor personen via internetfora op een online anonieme wijze met elkaar in contact kunnen komen zonder daarbij traceerbaar te zijn. ${ }^{37}$ Het Darkweb biedt daardoor kansen aan klokkenluiders, journalisten en inwoners van communistische landen waar het gebruik van internet gecensureerd wordt, om zo op een veilige en anonieme manier met de buitenwereld te communiceren, ${ }^{38}$ maar biedt ook kansen voor criminelen om op een nieuwe, veilige en anonieme wijze met elkaar te communiceren. ${ }^{39}$ Gezien de stijgende populariteit van het gebruik van het Darkweb en zijn fora onder criminelen, ${ }^{40}$ is het van belang dat er meer kennis wordt opgedaan over dit fenomeen, met als doel de mogelijkheden en kansen om de criminaliteit op het Darkweb te bestrijden te doen groeien. ${ }^{41}$ Echter, op dit moment staat het wetenschappelijk onderzoek naar het fenomeen rondom Darkweb-fora nog in de kinderschoenen en is er nog niet veel bekend over wat er hier nu daadwerkelijk op welke manier wordt gezegd. Dit onderzoek laat zien dat het met behulp van een checklist mogelijk is om online gesprekken te beoordelen, waardoor deze als kwantitatieve data kunnen worden behandeld. Met het huidige onderzoek is dan ook geprobeerd een gedeelte van de leemtes in de reeds bekende wetenschappelijke studies omtrent het Darkweb en zijn fora op te vullen. Daarnaast dient dit verkennende onderzoek met name als eerste stap voor meer, noodzakelijk, toekomstig onderzoek naar dit fenomeen.

Voor deze studie is een databestand samengesteld van 198 forumgesprekken, bestaande uit 2182 verschillende forumberichten afkomstig van het Agora-webforum. Aan de hand van dit databestand zijn er analyses uitgevoerd met als doel het vinden van verbanden tussen verschillende forumgebruikers om de werkende mechanismen achter een online Darkweb-forum beter te leren begrijpen. Geconcludeerd kan worden dat er wel degelijk bepaalde patronen en structuren binnen Darkweb-fora zijn te vinden. Verschillende typen forumgebruikers tonen significante verbanden met de rol die zij als forumgebruiker op het Darkweb op zich nemen en het type delict waarover wordt gesproken. Daarnaast kan de conclusie worden getrokken dat een Darkweb-forum vooral gezien moet worden als een virtuele ontmoetingsruimte zoals Soudijn en Monsma dit hebben beschreven, waar- 
bij het forum dienstdoet als een online plaats waar nieuwe connecties gelegd kunnen worden en netwerken verbreed. ${ }^{42}$ Ten slotte is het opvallend dat veel forumberichten gaan over het schrijven van reviews en over het delict drugs. Met name deze laatste bevinding is opvallend, aangezien er niet specifiek is gezocht naar drugsberichten, maar naar malwareberichten. Echter, wanneer wordt gekeken naar de studie van Van Hout en Bingham blijkt dat de respondenten met name actief zijn op het forum vanwege de interesse in drugs. ${ }^{43}$ Wellicht geeft deze studie dan ook een signaal af dat de handel in drugs zich langzaam van de straatmarkt verplaatst naar de digitale markt. De hoge score op het aantal reviews is wellicht te verklaren aan de hand van de eerder omschreven crime scripts, waarbij Hutchings en Holt het in de laatste fase van het script hebben over reputatiemanagement. ${ }^{44}$ Forumgebruikers lijken toch behoefte te hebben aan een meetbaar instrument waaraan afgelezen kan worden of andere forumgebruikers betrouwbaar zijn.

\section{Discussie}

Ondanks de getrokken conclusies kent dit onderzoek ook een aantal beperkingen. Zo zijn er net als bij het onderzoek van Hutchings en Holt beperkingen op het gebied van representativiteit en generaliseerbaarheid. ${ }^{45}$ Omdat er op dit moment nog vrijwel geen vergelijkbaar onderzoek uitgevoerd is naar Darkweb-fora, is het lastig om de waarde van de steekproef en de bijbehorende resultaten in het juiste perspectief te plaatsen. Het is nu lastig om te bepalen of de huidige steekproef en resultaten als normaal mogen worden beschouwd, of juist als opvallend en verrassend.

Een tweede beperking aan deze studie is het gevaar van subjectiviteit die de onderzoeksmethode met zich brengt. ${ }^{46}$ Ondanks dat de variabelenlijst nauwkeurig is samengesteld door zowel te kijken naar eerdere literatuur als naar de beschikbare dataset, leidt de vrijheid die de onderzoeksmethode met zich brengt tot mogelijke subjectiviteit. Het is bijvoorbeeld mogelijk dat een thread of bericht onder meerdere categorieën ingedeeld zou kunnen worden, waardoor er keuzes zijn gemaakt die door andere onderzoekers anders geïnterpreteerd kunnen worden. Gezien de werkwijze die bij deze onderzoeksmethode wordt gehanteerd, zal het onder alle omstandigheden lastig zijn om deze geheel objectief toe te passen.

De laatste beperking binnen dit onderzoek is selectiviteit. Voor de steekproeftrekking is ervoor gekozen om deze strikt af te bakenen, waardoor het mogelijk is dat er threads met specifieke kenmerken zijn geselecteerd. Het is dus mogelijk dat deze resultaten een vertekend beeld van de werkelijkheid geven, en dat de keuze voor andere steekproefvoorwaarden tot andere resultaten had geleid. Voor het huidige onderzoek is selectiviteit in beginsel niet per definitie een probleem. Het 
doel van het onderzoek is immers niet gericht op het specifiek beschrijven van één bepaald delict, maar om het beter leren begrijpen van de werkende mechanismen van Darkweb-fora. ${ }^{47}$

Ondanks deze beperkingen geeft het huidige onderzoek naar online internetfora wel een goede eerste blik op patronen en structuren op Darkweb-fora en vormt het een goed startpunt voor vervolgonderzoek. Daarnaast laat het huidige onderzoek nogmaals zien dat de klassieke vormen van criminaliteit zich niet alleen meer op straat afspelen, maar dat deze zich ook verplaatsen naar de virtuele ruimte. De huidige kennis naar het Darkweb en zijn fora is op dit moment nog niet toereikend genoeg om hier effectieve en efficiënte maatregelen tegen in te zetten, waardoor het belangrijk is dat deze kennis wordt uitgebreid middels nieuw wetenschappelijk onderzoek. Meer kennis moet het mogelijk maken voor opsporingsinstanties om gemakkelijker en professioneler te infiltreren binnen Darkweb-fora. Duidelijk is in ieder geval dat er voor zowel de wetenschappelijke als de maatschappelijke wereld maar één vraag centraal staat met betrekking tot Darkweb-fora: wat wordt er nu eigenlijk gezegd? 